Fecha de recepción: marzo 2020 Fecha de aceptación: abril 2020 Versión final: mayo 2020

\section{Os erros mais comuns cometidos pelos Consultores de Imagem na hora de aplicar um plano de Marketing no negócio}

Fernanda Luchesi ${ }^{(1)}$

Resumo: O intuito desse artigo é informar aos Consultores de Imagem quais são os principais elementos que afetam o desempenho positivo, efetivo e ágil do plano de Marketing em seus negócios. Assim como indicar alguns caminhos para sanar esses desafios. Foram anos de estudos na área de Marketing e Comunicação, além de aplicações práticas no mundo da Consultoria de Imagem. Adquiri informações e conhecimento por meio dos resultados no meu negócio, dos meus alunos e mentorandos, além de pesquisas. Concentrei os erros mais comuns em três pilares que irei chamar de Tríade do Plano de Marketing. São eles, a falta de Clareza, falta de Organização e a falta de Habilidades. O mercado está precisando de Consultores de Imagem, e a sua missão é fazê-los lhe encontrar e querer seus serviços, por meio do Marketing.

Palavras chave: Plano de Marketing - Marketing Digital - Consultor de Imagem - Marketing - Consultoria de Imagem - Marketing e vendas.

[Resumos em espanhol e inglês nas páginas 104-105]

(1) Fê Luchesi é Especialista em Imagem Profissional para Executivas \& Marketing Digital para Consultores de Imagem. Certificada em Consultoria de Imagem pela FIT (Fashion Institute of Technology - NY). Marketing \& Social Media Analysis pelo MIT de Boston/ EUA. Etiqueta e Produção de Moda no Senac. Coach pela SBC, Branding pela ESPM, Pós em MKT pelo Insper, e Trainer pela Success Resources/Experiência de Sucesso, Vendas e Liderança na FGV. Board da AICI (Associação Internacional de Consultores de Imagem). É a quinta brasileira a obter a Certificação Internacional CIC (Certified Image Consultant). Já atuou como Stylist Assistant na Fashion Week de NY e em fashion shows na Macys/NY. Palestrou para Coca- Cola, Visa, Estee Lauder, Latam, Ericsson, P\&G, Teresa Perez e Hospital Albert Einstein, além de facilitar treinamentos e palestras no México, Chicago, Washington e Porto Rico. Já teve seu nome em revistas como ELLE, Marie Claire, Cosmopolitan e Jornal Folha de São Paulo. Coautora do Curso Online Universidade da Mulher Poderosa e do livro Empodere-se AGORA. 


\section{Introdução}

O mercado de Consultoria de Imagem vive uma fase de expansão na América Latina, o que nos deixa, profissionais da área, muito felizes e ao mesmo tempo preocupados com o aumento da Concorrência. Por isso, hoje, mais do que nunca, existe a necessidade de um posicionamento de mercado mais profissional e de forma mais rápida, aplicando um plano estratégico de Marketing Digital. Esse plano deve ser efetivo e moderno para fortalecer e expandir o negócio. Parece uma saída fácil, óbvia e perfeita, porém na vida real é bem diferente. O primeiro desafio está em conseguir criar um plano de Marketing, e o segundo está em aplicar esse plano, apesar de tantas interferências, do próprio negócio e da vida pessoal. Dessa forma, é nessa hora que começam os erros mais comuns que os Consultores de Imagem cometem ao aplicar um plano de Marketing no seu negócio. Entenda os três pilares que complicam a vida de um Consultor, caso sejam negligenciados. São eles, a falta de Clareza, falta de Organização e a falta de habilidades.

\section{Falta de Clareza}

"A maior parte das pessoas não chegam onde querem, por não saberem o que querem" Conrado Adolpho (2018), um especialista brasileiro em Marketing Digital para empreendedores. Sem uma ideia do que o Consultor almeja para seu negócio e para sua vida, é muito difícil conseguir criar um plano efetivo que irá completar os anseios do Consultor de Imagem. A sensação de fracasso e perda de tempo irá prevalecer na maior parte do tempo, pois não fica claro quais são os objetivos a serem cumpridos no dia a dia. Há somente uma ilusão de um futuro perfeito e feliz sem ações factíveis para atingí-lo. Essa clareza surge por meio de decisões e vivências. Quanto mais vivência e ações, mais informações serão colhidas para tomar decisões mais assertivas. No entanto por medo de errar, medo de perder tempo ou medo de passar vergonha, o Consultor evita riscos. Com isso evita grandes aprendizados e crescimento que irão cooperar para ter mais clareza do que ele realmente gosta, e o que é bom para seu negócio.

Ao selecionar um dos caminhos disponíveis ao empreendedor, será possível afunilar as possibilidades, e seu plano de Marketing poderá ser desenvolvido com mais clareza. As certezas na carreira acontecerão quando forem testadas e colocadas em prática.

Ou seja, escolha uma direção a seguir, mesmo que não se tenha plena certeza de que será a certa. Fique com ela por pelo menos seis meses para dar tempo de fazer análises e colher algum resultado. Dessa forma o Consultor começará a eliminar possibilidades que não foram positivas e ter mais certeza dos seus objetivos.

\section{a. Visão de Negócio}

Em todos os atendimentos, mentorias e cursos que ofereço, começo orientando o Consultor de Imagem a visualizar onde quer chegar, o que pretende fazer, quem atender e 
quando gostaria de atingir esse resultado (vide figura abaixo). Todo processo da carreira se inicia com uma intenção, porém se ela não tiver uma direção, irá aumentar a sensação de desperdício de tempo e dinheiro, além de frustrações.

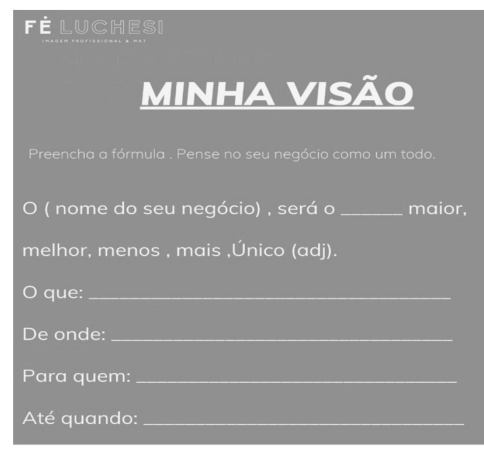

Figura 1. Fórmula da Visão de Negócios. Fonte: Método 8ps (2018).

Mesmo que a pessoa esteja no início da carreira, esse exercício ajudará a pensar de maneira mais racional e precisa. É muito importante que a visão seja escrita em um papel, ou digitada para realmente organizar as ideias. Pode parecer impossível pensar no futuro, porém iniciar esse rascunho orientará o Consultor a pensar em uma rota para o destino desejado ou imaginado, para assim fazer a elaboração de um plano de Marketing congruente. De acordo com a Pesquisa Causa Mortis, Sebrae (2014), 85\% das empresas que estão no marcado há mais de cinco anos estabeleceu aonde queria chegar.

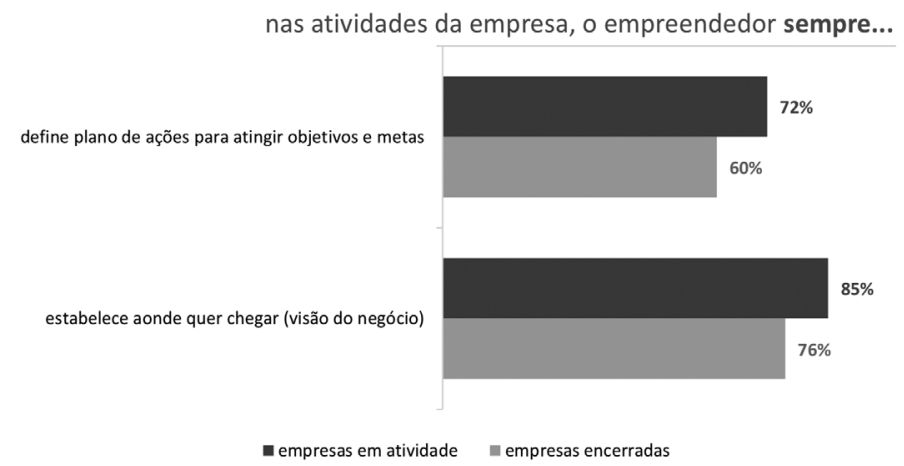

Figura 2. Comportamento Empreendedor Sebrae. Fonte: Pesquisa Causa Mortis. Sebrae 2014. 
A visão poderá ser ajustada no meio do caminho, mas pelo menos, o Consultor nessa altura, já estará mais seguro das suas escolhas.

Os resultados de uma pesquisa realizada por mim, em fevereiro de 2020, sobre as Informações do Negócio de Consultoria de Imagem no Brasil (Luchesi, 2020), com 55 Consultores de Imagem brasileiros, demonstraram que 51\% escreveram sua Visão de Mercado, ou seja, uma taxa menor ainda do que as empresas que já não estão no mercado (60\%), de acordo com o Sebrae.

Outra vez, pela voz de Conrado Adolpho: "Não existe estratégia se não existe um objetivo claro. E não existe um objetivo claro, se não existe uma visão de futuro", ou podemos citar o famoso livro de Stephen Covey, os Sete Hábitos das Pessoas Altamente Eficazes (2003), afirma que para ser uma pessoa altamente eficaz deve-se iniciar com o fim em mente. Toda startup inicia no mercado com uma visão muito clara, com números, especulações e plano de Marketing bem convincentes, especialmente para conseguirem captar recursos de investidores. Sem isso, não há negócio.

"Se você não tem objetivos, não tem foco; e, infelizmente, neste momento, ainda você não tem nada" (Bendec, 2009, p. 141).

Ao encarar o negócio de Consultoria de Imagem como uma Startup em busca de crescimento, posicionamento e lucro, trabalharemos de forma bem mais focada, organizada e direcionada.

\section{b. Nicho de mercado}

Como em muitos mercados, aqueles que se destacam e têm mais resultados financeiros, são aqueles que conseguiram se posicionar primeiro na mente do consumidor. Para que isso aconteça é necessário um trabalho de Marketing para que as pessoas desejadas identifiquem e reconheçam a empresa de acordo com o que elas buscam. Se o Consultor não sabe com quem ele está falando, e não conhece profundamente o seu nicho, a comunicação do plano de Marketing não conseguirá levar a mensagem certa para a pessoa certa, e não cooperará com o posicionamento do Consultor. Também dificilmente haverá reconhecimento e empatia por parte do cliente.

O professor e autor $\mathrm{Al}$ Ries, pai da palavra Posicionamento, afirma que quando a empresa ou Consultor é conhecida como a primeira, ou seja, ela é a pioneira em alguma área específica ou abriu o mercado, ela será a primeira a conseguir encontrar um espaço e construir uma posição na mente do consumidor. Hoje em dia é quase impossível lembrar quem é o segundo melhor do mercado, ou o segundo lugar nas Olimpíadas ou Oscar, mas o primeiro sempre será lembrado. O primeiro sempre terá uma grande vantagem competitiva na mente do consumidor. Encontre algo para ser o primeiro. Qual é a palavra, ou conjunto de palavras que definem a sua marca? Pois assim, ao serem pronunciadas, serão atreladas ao seu negócio.

Caso o Consultor de Imagem não seja o primeiro do mercado em sua região, ele terá que encontrar uma maneira de ser lembrado por algo mais específico, para se posicionar e ajudar o consumidor a lembrar dele. 
Hoje em dia, com uma enxurrada de informações e uma overcommunication que temos, nossa mente não consegue lembrar de serviços e pessoas, o barulho é muito alto. A mente humana tem uma limitação de memória por categoria.

Ao conseguir atrelar a sua marca com uma palavra, uma descrição ou um sentimento, será mais fácil para o cliente fazer a correlação com suas categorias existentes e arquivar em sua memória.

"O cérebro humano é hábil em reconhecer itens semelhantes e colocá-los em categorias" (Trafton, 2011, MIT News Office).

Encontre seu pote de diamantes, ou seja, seu nicho lucrativo o mais breve possível para ser lembrado pelo seu público desejado (vide figura abaixo).

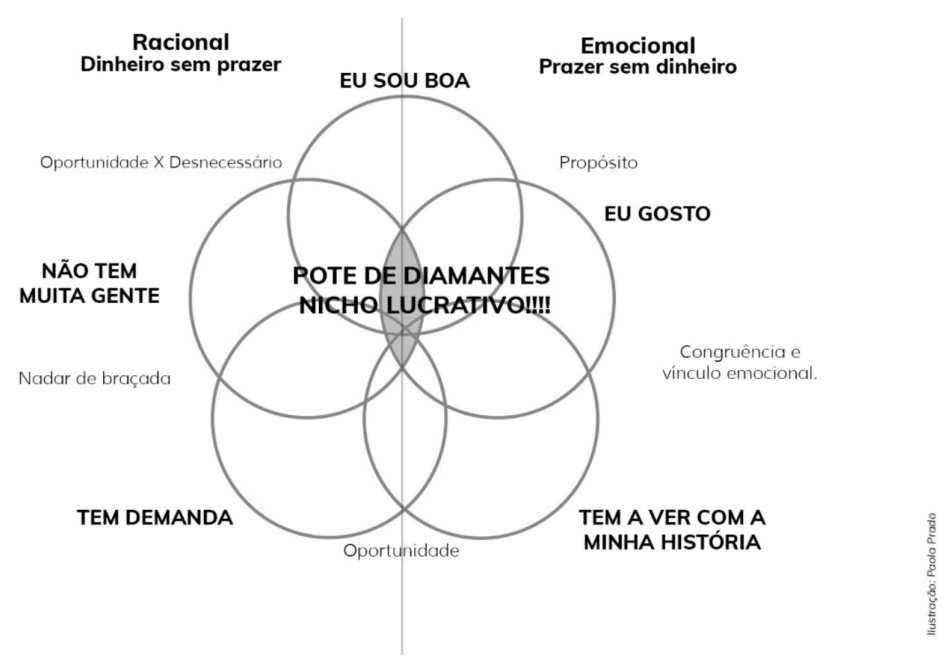

Figura 3. Pote de Diamantes | Nicho Lucrativo. Fonte: união da teoria de diversos autores sobre nicho.

"A sorte é uma comunicação de sucesso, onde se diz a coisa certa, para a pessoa certa, e na hora certa" (Al Ries, 2006).

O Consultor pode escrever os resultados que lhe vem na cabeça dentro dos círculos da figura 3. Ao final, deve compilar os dados, procurar semelhanças e selecionar uma direção a seguir. Os profissionais que são renomados no mercado de Consultoria chegaram primeiro, ou são conhecidos por alguma atuação, ou serviço específico. Faça uma lista dos principais nomes no mercado de Consultoria de Imagem, e escreva ao lado o motivo que faz ele ser o mais conhecido. Um dia o seu nome também poderá estar nessa lista. O que ela irá dizer sobre você? Sem o nicho, o plano de Marketing não terá força para ajudar no posicionamento do Consultor. 


\section{c. Números}

A minha pesquisa com Consultores de Imagem brasileiros (Luchesi, 2020) demonstrou que apenas $20 \%$ tem total ou muita facilidade com números.

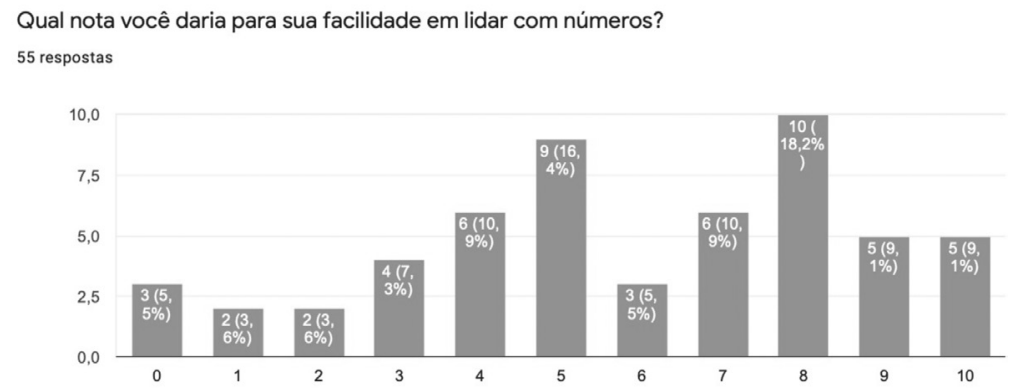

Figura 4. Facilidade em lidar com números.

Além disso, apenas 14\% tem total ou muito conhecimento de gestão de Empresas.

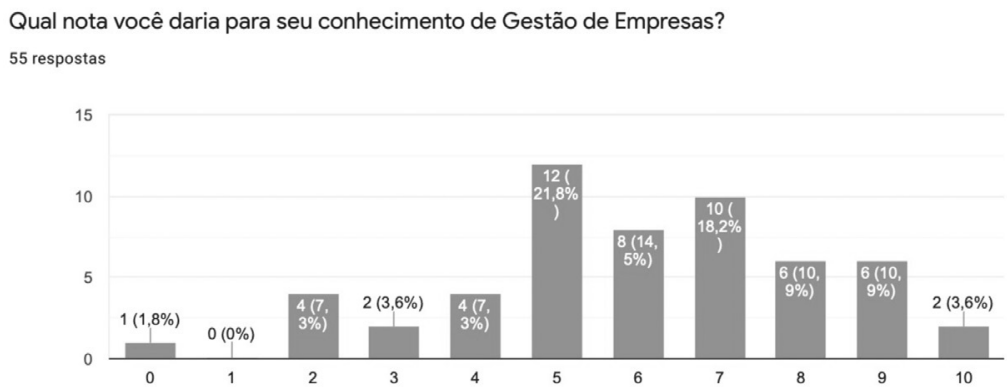

Figura 5. Conhecimento em Gestão de Empresas.

Porém são esses conhecimentos que farão o Consultor de Imagem ter seu negócio em mãos, com total controle, e gerenciá-lo como um negócio profissional. A ineficiência de gestão foi um dos quatro fatores críticos para que empresas fechassem em menos de cinco anos, como apresentado na pesquisa do Sebrae de 2016 sobre a sobrevivência das empresas no Brasil. 
... entre as empresas que continuavam em atividade, havia uma menor proporção de desempregados, e uma maior proporção de empresários com maior experiência no ramo, que abriram o negócio porque identificaram uma oportunidade e/ou que desejavam ter o próprio negócio, que tiveram mais tempo para planejar, que conseguiram negociar com fornecedores e obter empréstimos em bancos, que aperfeiçoavam seus produtos/serviços, que investiam na capacitação da mão-de-obra, que inovavam mais, que faziam o acompanhamento rigoroso de receitas e despesas, que diferenciavam seus produtos em relação ao mercado e que investiam na sua própria capacitação em gestão empresarial (Sebrae, 2016).

O Plano de Marketing está relacionado com a Gestão da empresa, e se não estiver atrelado à números, ou seja, ganhos por mês, o plano de Marketing será apenas um sonho e aumentará a chances de ser altamente esquecido, e visto uma única vez ao ano. As ações definidas em um planejamento precisam contribuir para a conquistas das metas financeiras. Esse planejamento macro, como na figura abaixo, é um guia para definir as ações micros semanais para conquistar o objetivo traçado.

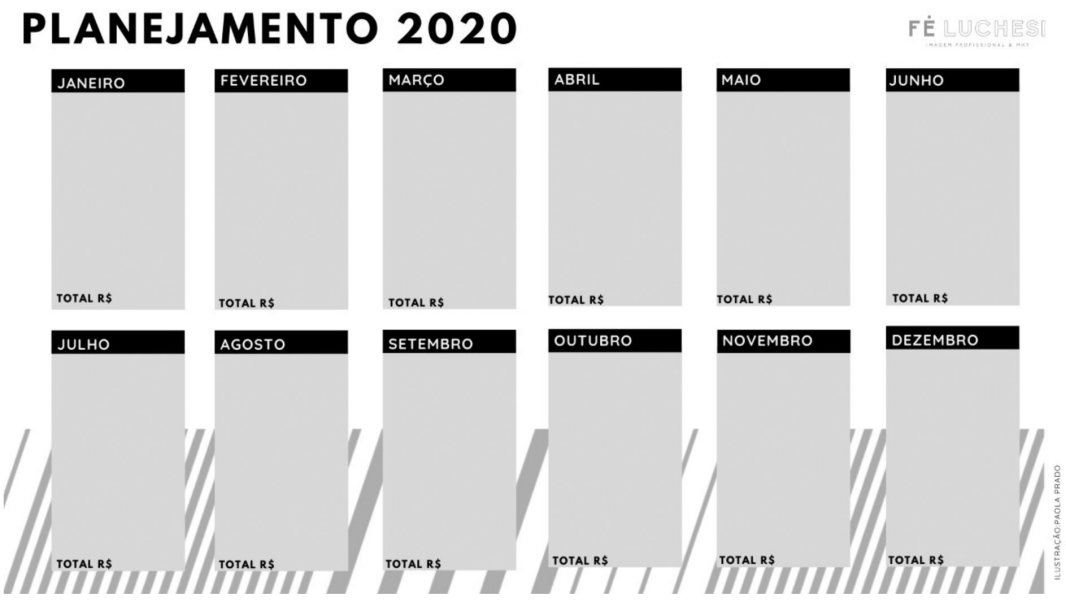

Figura 6. Planejamento Anual de Receitas. Ilustração: Paola Prado.

De acordo com minha pesquisa (Luchesi, 2020), 71\% dos Consultores não fizeram um plano de Marketing em 2020, e 66\% também não haviam feito o planejamento financeiro para 2020, mesmo já tendo passados dois meses do ano. Na figura abaixo realizei uma comparação do cenário do mercado de Consultoria de Imagem no Brasil com as empresas 
que sobreviveram após cinco anos. $\mathrm{O}$ intuito foi entender quais são os pontos de atenção para fazer melhorias, e nos manter por mais tempo com negócios saudáveis no mercado.

\begin{tabular}{|c|c|c|c|c|c|}
\hline \multicolumn{2}{|c|}{ FATORES CONTRIBUINTES } & \multicolumn{2}{|l|}{ EMPREESAS ATIVAS APÓS 5 ANOS } & \multicolumn{2}{|l|}{ EMPRESAS DE CONSULTORIA DE IMAGEM } \\
\hline \multirow{4}{*}{ SITUACAO ANTES DA ABERTURA } & CONOMKO ANTEROROR DO EMPRESSAMO * & MENOR proporção de desempregodos (21\%) & 0 & $\begin{array}{l}\text { Normalmente há transiḉ̧o de carr reira e năo } \\
\text { desemprego para motivar escolher a Consultoria, } \\
\text { openas desconforto com profissão anterior. }\end{array}$ & $\boldsymbol{0}$ \\
\hline & 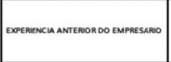 & $\begin{array}{l}\text { MAIOR proporçâo de pessoas com } \\
\text { experiência } \\
\text { anterior no mercodo ou ramo (71\%) }\end{array}$ & $\mathbf{t}$ & $\begin{array}{l}\text { MENOR proporçóo de pessoas com experiência } \\
\text { anterior no mercodo ou ramo }\end{array}$ & (1) \\
\hline & \multirow{2}{*}{ 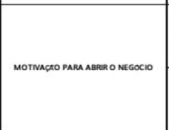 } & $\begin{array}{c}\text { MAIOR proporçāo dos que abriram pq } \\
\text { identificaram oportunidade ou desejovarm ter } \\
\text { o próprio negócio. (59\%) }\end{array}$ & $\mathbf{E}$ & $\begin{array}{l}\text { MAIOR proporçâo gostam de moda ou desejavam } \\
\text { ter o próprio negócio. }\end{array}$ & $\mathbf{0}$ \\
\hline & & $\begin{array}{l}\text { MENOR Proporçāo dos que obriram por } \\
\text { exigência de } \\
\text { cliente/fornecedor (12\%) }\end{array}$ & (3) & $\begin{array}{l}\text { MENOR Proporçāo dos que abriram por exigência } \\
\text { de cliente/fornecedor }\end{array}$ & (4) \\
\hline \multirow{5}{*}{ PLANEjAMENTO } & 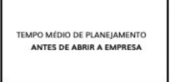 & 11 meses & $\mathbf{t}$ & $\begin{array}{l}\text { A confirmar. Acredito que poucos fizeram um plano } \\
\text { de negócio escrito com anólise de concorrentres, } \\
\text { valores, riscos, SWOT, metos e tempo necesóario } \\
\text { paro a transiçăo da carreiro. }\end{array}$ & (0) \\
\hline & \multirow{4}{*}{ ascursos } & $\begin{array}{l}\text { MAIOR proporção negociou prozos com } \\
\text { fornecedores ou obteve empréstimo em } \\
\text { boncos } 39 \%\end{array}$ & $\mathbf{1}$ & $\begin{array}{c}\text { MENOR proporção negociou prazos com } \\
\text { fornecedores ou obteve empréstimo em bancos, } \\
\text { pois nôo há grandes borreiras de entroda ou } \\
\text { necessidade de estoques altos. }\end{array}$ & D \\
\hline & & $\begin{array}{l}\text { Estar sempre otualizado com respeito as } \\
\text { novas tecnologias do seu setor (78\%) }\end{array}$ & $\mathbf{t}$ & $\begin{array}{c}\text { Acredito ser o caso de boo parte dos Consultores } \\
\text { do Brasil. }\end{array}$ & $\mathbf{t}$ \\
\hline & & $\begin{array}{l}\text { Investir na capacitoşa da măo de obra e } \\
\text { dos sócios (52\%) }\end{array}$ & 0 & $\begin{array}{l}\text { Serio onde mois se investe. Mois do que em } \\
\text { recursos, marketing, equipe e materiois. }\end{array}$ & $\mathbf{0}$ \\
\hline & & \begin{tabular}{|c|}
$\begin{array}{c}\text { Realizar um acompanhamento rigoroso da } \\
\text { evoluçăo das receitas e das despesas ao } \\
\text { longo do tempo } 65 \%\end{array}$ \\
\end{tabular} & $\mathbf{0}$ & $\begin{array}{l}\text { É feito por 37,3\%. Nõo há controle rigoroso. Muitos } \\
\text { nốo sobem seu custo fixo, e crescimento anual. }\end{array}$ & 0 \\
\hline GESTAO DO NEGOCIO & 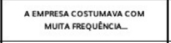 & Diferenciar produtos e serviços (31\%) & $\mathbf{t}$ & $\begin{array}{c}\text { A maioria vende os mesmos serviços e nāo vorio } \\
\text { muito. }\end{array}$ & 0 \\
\hline $\begin{array}{l}\text { CAPACITAÇ̄o EM GEST̃̃o } \\
\text { EMPRESARIAL }\end{array}$ & 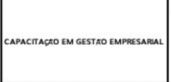 & $\begin{array}{c}\text { MAIOR proporçăo que fez olgum curso para } \\
\text { melhorar o conhecimento sobre como } \\
\text { administrar um negócio, enquanto tinha a } \\
\text { empresa (51\%) }\end{array}$ & $\mathbf{0}$ & $\begin{array}{l}\text { Acredito que a moioria aprende junto com o } \\
\text { negócio e nōo faz uma pauso para aprender como } \\
\text { odministrar. }\end{array}$ & 0 \\
\hline
\end{tabular}

Figura 7. Comparativo da Mortalidade com o mercado de Consultoria de Imagem.

De acordo com a figura acima, os Consultores são extremamente estudiosos, procuram estar antenados com as novas tecnologias do setor e querem empreender em algo diferente da sua profissão anterior. Também são muito ligados com a Moda. Porém a maioria não são profissionais que tinham experiência na área, ou que realizaram planos de negócio estruturados. Também há uma baixa aptidão para administrar a empresa. As empresas com mais de cinco anos no mercado controlam o negócio $50 \%$ a mais, e têm um rigoroso controle financeiro. Assim sendo, os pontos de melhoria para que o negócio de Consultoria floresça por mais de cinco anos, estão em ter uma experiência maior na área, planejar melhor o negócio antes de abrir, realizar um acompanhamento rigoroso de receitas e despesas, e melhorar o conhecimento de gestão de empresas. Os pontos fortes do negócio de Consultoria são alto grau de estudo e educação dos Consultores, atualização constante e baixo custo fixo no negócio, não havendo necessidade de empréstimos no banco. 


\section{d. Autoconhecimento}

Estamos em uma era do “ser", em contrapartida com o “ter”. Está na moda meditar, ir para retiros espirituais, yoga, e cursos de autoconhecimento. Todos são altamente recomendáveis para que a pessoa volte seu olhar para dentro de sí. Isso poderá ajudar para que ela possa chegar à respostas valiosíssimas para empreender e entender melhor o processo que irá passar. Pela pesquisa com Consultores de Imagem (Luchesi, 2020), 87\% dariam uma nota 7 a 9 para seu autoconhecimento e $2 \%$ daria nota 10 . Por terem uma nova chance de mudança de vida e de escolha de carreira, uma grande etapa de autoconhecimento já foi alcançada por quase todos os Consultores pesquisados.

Quando o Consultor de Imagem consegue passar pelas etapas abaixo, e conquista respostas claras, seu autoconhecimento aumenta ainda mais, e o plano de Marketing e gerenciamento da sua empresa são totalmente competitivos e relacionados à sua essência.

\section{i. Diferenciação}

A primeira fase em um plano de negócios é fazer uma análise SWOT, ou FOFA (fraquezas, fortalezas, ameaças e oportunidades). No caso do Consultor de Imagem, essas respostas estão interligadas à personalidade do próprio Consultor. São elas que no final vão direcionar um plano de Marketing e um discurso de vendas. Se essa análise não for feita logo de início, a comunicação poderá ser igual a dos seus concorrentes, e não conseguirá mostrar ao seu consumidor o seu diferencial, portanto não venderá como imagina, e não se posicionará no mercado.

"A estratégia da diferenciação mostrou-se mais vantajosa para a permanência das empresas no mercado do que a estratégia de custos" (Sebrae-SP. Pesquisa Causa Mortis, 2014). Ficará desafiador conquistar o espaço na cabeça do consumidor por falta de diferenciação. Quem é você? Por que você é um Consultor de Imagem especial e pode fazer da vida das pessoas especial? Não seja tão humilde nesse momento. Faz parte da nossa cultura, atrelar à arrogância a valorizar a si mesmo. Ou seja, se você diz que é bom, é arrogância. Isso foi inibindo as pessoas de reconhecerem, e se sentirem orgulhosas de suas habilidades e talentos. Esse é o momento de olhar para o passado, listar tudo que você fazia bem, como atividades físicas, mentais, sociais, criativas, e se orgulhar delas. Elas vão dizer muito sobre os diferenciais de um Consultor.

\section{ii. Autoconfiança}

Quem vende Imagem e transformação precisa ter autoconfiança para vender o seu serviço. Um plano de Marketing precisa da gasolina da autoconfiança para ser colocado em prática, pois estará diretamente atrelado à pessoa física do Consultor. São diversos casos de Consultores que não aplicam o que planejam por vergonha, medo do julgamento e perfeccionismo. O medo está presente para todas as pessoas, inclusive para os autoconfiantes. "É claro que existe uma forma mais simples de curar o medo: não se colocar em situações de risco. Mas se você tem espírito empreendedor, não pode sequer contar com essa possibilidade porque o medo é inerente ao processo" (Rocha, 2016). 
A autoconfiança está atrelada à quanto você acredita que tem atributos positivos e consegue dar o melhor de si. Muitos não se sentem aptos por não terem ainda um resultado financeiro que almejam, no entanto, os números vão crescer junto com a sua autoconfiança. Muitos também imaginam que necessitam ter tudo pronto e impecável antes de comunicar e vender algo. Mas a confiança em sí vem com testes e refinamentos.

Costumo dizer que se o Consultor sente que não faz nada direito, que nada dá certo, e que está prestes a desistir porque não tem resultados financeiros, ele deve começar a listar suas conquistas e celebrar diariamente as pequenas. Esses pequenos atos tem um poderoso gatilho em nossa mente.

Ao celebrar, você reforça um comportamento desejado. Isto está bastante associado à construção de hábitos e a teoria do Poder do Hábito escrito por Charles Duhigg, onde a recompensa é o fator principal para solidificar um certo comportamento. Quando você diz a você mesmo "bom trabalho!" esta ação faz com que o cérebro crie uma forte conexão entre esta recompensa e o comportamento que te levou a ela (Alves, 2016).

De acordo com o TEDxAtlanta em 2011 da Teresa Amabile, uma pesquisadora de Harvard em experiências psicologias e performance, incentivar, valorizar e celebrar os pequenos progressos geram enormes benefícios para a empresa.

Comece agora a celebrar e construir uma imagem de pequenos sucessos que alimentam sua autoconfiança. Quando se nutre a autoconfiança, as chances de vendas são maiores, e a quantidade de energia para aplicar seu Plano de Marketing também.

\section{iii. Paciência}

Um Consultor de Imagem não é uma empresa tradicional, mas sim uma empresa que normalmente inicia com uma pessoa apenas. Essa única pessoa deverá fazer tudo que seria dividido entre vários profissionais especializados. Logo, o tempo para que as ações do Plano de Marketing e os resultados expressivos comecem a acontecer poderão demorar. Ademais, caso o Consultor de Imagem venha de outra profissão, como é o caso de 95\% dos entrevistados pela pesquisa Informações de Negócio da Consultoria de Imagem (Luchesi, 2020), contribuirá ainda mais, pois junto à sua busca por formação, aperfeiçoamento e processos de abertura da empresa, ele estará aprendendo e fazendo tudo junto ao mesmo tempo. Uma graduação tradicional, início de carreira, e até chegar a um bom cargo levam em média 10 a 15 anos para acontecerem, no entanto os Consultores de Imagem imaginam que ao trocar de carreira conseguirão um resultado expressivo em seis meses, um ano, e isso é raramente verdade. O que é mais provável acontecer é conseguir o retorno dos investimentos (ROI) de maneira mais rápida que a convencional.

Os dados da pesquisa Informações de Negócio da Consultoria (Luchesi, 2020) indicam que o ROI para Consultores que se dedicam 100\% á carreira é de até um ano em 23\% dos casos, e de um a dois anos também em $23 \%$ dos casos. Aqueles que não tiveram ROI somam 39\%. De acordo com a pesquisa, as principais causas para que os consultores dedicados não tivessem o ROI foram: não ter planejamento de marketing ou financeiro, ter 
nota 6 para autoconhecimento, para vendas, para conhecimento de marketing digital e para facilidade com números. E $80 \%$ é a primeira vez que empreende e estão pouco posicionados no mercado.

\section{CONSULTORES 100\% DEDICADOS}

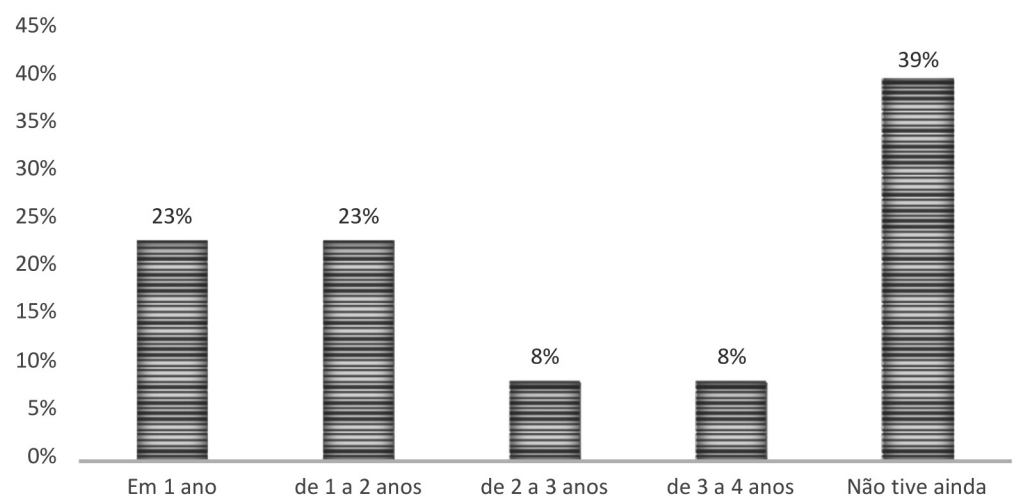

Figura 8. ROI x Consultores 100\% dedicados.

Outro ponto de atenção, foi que Consultores que não se dedicam 100\% à Consultoria, não tiveram retorno do Investimento ainda. Ou seja, se o Consultor dividir sua rotina com outro trabalho, o ROI demorará ainda mais para chegar, ou não irá chegar, e por consequência os lucros também não. Caso o Consultor esteja esperando os trabalhos de consultoria darem lucro para depois mudar de carreira, essa não será a fórmula do sucesso. Mais certeiro será trabalhar mais em sua carreira anterior, fazer uma reserva financeira para poder trocar de carreira e investir no negócio de Consultoria de Imagem. 


\section{CONSULTORES C/ OUTRA PROFISSÃO}

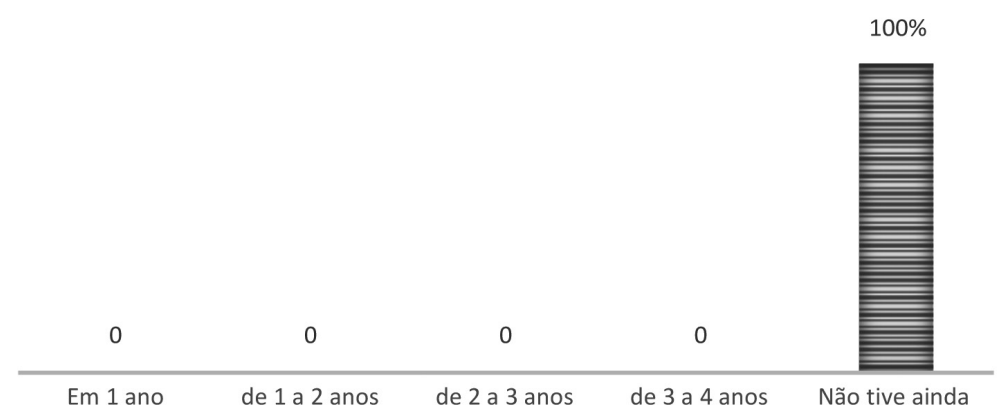

Figura 9. ROI x Consultores com outra profissão.

Trabalhar com Marketing é trabalhar com incertezas, testes, análises e novos testes, até encontrar o melhor caminho. Leva-se tempo e dinheiro para atingir resultados expressivos. Deixo aqui claro, que ter paciência não é esperar sem agir, mas sim, agir, analisar, trocar a rota, agir novamente, analisar e agir de novo. Sempre tentando melhorar. Portanto uma dose de paciência, agitação e inquietação é necessária, e é benéfico para a implantação do Plano de Marketing e crescimento da empresa.

\section{iv. Inteligência Emocional}

Lidar com pessoas e criar seu próprio negócio é um processo contínuo de altos e baixos, e consequentemente lidar com frustrações faz parte dele. O Mark Manson, autor do livro A sutil arte de ligar o f $^{\star}$ da-se (2016), nos ensina que a vida é um grande problema, e que se formos excelentes "resolvedores" de problemas, não sofreremos tanto quando um deles aparecer. Saberemos o que fazer e como lidar com eles da melhor forma possível naquele momento. Quando o problema ou frustração aparecem, eles vêm carregados de emoções, e a pessoa é a responsável em abanar o fogo, ou apagá-lo. Esse treinamento da mente em relação as expectativas do negócio tendem a beneficiar o profissional, lhe dando economia de tempo e energia para aplicar seu plano de Marketing com mais leveza. Ele estará mais preparado para enfrentar suas frustrações, que com toda certeza vão aparecer em algum momento. Ser inteligente emocionalmente é conseguir se colocar fora de situações que vão atrapalhar o bom andamento do plano. Ou perceber quando uma situação está começando a atrapalhar, e logo tomar uma decisão calma sem grandes prejuízos emocionais. É uma prática constante. 


\section{v. Mindset}

Um dos livros mais famosos sobre mentalidade é o da Carol S. Dweck, Mindset (2017). Onde ela apresenta os dois tipos de mentalidade. A mentalidade fixa e a mentalidade construtiva. Um Consultor de Imagem empreendedor, necessita desenvolver uma mentalidade Construtiva, onde ele irá aprender com os erros e usá-los para melhorar cada dia mais. Desenvolver um mindset construtivo faz com que a busca por aprendizado e desafios sejam constantes, e ajudará a enfrentar a falha como aprendizado. O mindset construtivo observa os esforços como caminho para o sucesso, e persiste quando vê obstáculos. Não foca nos problemas e sim na solução, e não evita falhas ou sente-se ameaçado com o sucesso dos outros Consultores. Ao entender que a inteligência e habilidades podem ser desenvolvidas, o Consultor segue um caminho mais leve e percebe que a jornada é mais importante que o destino. Ele aprende a apreciar os processos, os tombos, as falhas, as frustações e os sucessos. A mentalidade de um empreendedor que tem que criar um plano de Marketing para si, é diferente daquele que está criando um plano para a empresa do Chefe. Quando o plano será executado somente pelo Consultor, ele escolhe se irá colocar em prática ou não, ou se irá de fato criar um plano de Marketing. As consequências serão somente do Consultor. E se algo não for finalizado como previsto, como acontece constantemente, o Consultor com um mindset fixo acreditará em sua voz interior que diz "eu não sou bom nisso".

A mentalidade de um empreendedor preparado irá cooperar com desenvolvimento de um plano de Marketing que siga os benefícios da Meta S.M.A.R.T., que significa, Específico, Mensurável, Atingível, Relevante e em um Tempo. Na prática, o SMART se aplica da seguinte forma no campo da Consultoria de Imagem.

i. Específico: Um plano específico ajuda para que o plano de Marketing seja Claro, com detalhes e não com informações soltas. Um plano Específico seria algo como a fórmula da Visão (figura 1), como por exemplo criar estratégias e táticas para ser reconhecido como o primeiro Consultor de Imagem da Cidade " $x$ " a trabalhar com mulheres acima de sessenta anos que querem sentirem-se modernas e confiantes no ato de vestir sua Imagem em viagens. Nosso cérebro consegue categorizar e organizar com mais facilidade quando lhe damos dados detalhados.

j. Mensurável: O plano que é mensurável, coopera para que o Consultor tenha uma forma de medir se ele está sendo realizado com sucesso, ou não. Toda vez que uma meta e um plano têm números, há uma forma visível de mensurar, pois os dados ajudam a criar gráficos que facilitam a visualização do negócio. As pessoas tendem a entender imagens mais facilmente do que números numa planilha. Coloque seus números de seguidores ou vendas mensais num gráfico de linha, que você terá uma nova visão de como está a consequência do Plano de Marketing no seu negócio. Consequentemente ele resultará em elevar a motivação, pois fica mais claro para analisar se algo está caminhando bem ou não. Um plano mensurável deveria mostrar, por exemplo, um crescimento de $20 \%$ em vendas em relação ao ano anterior, ou que 50\% dos clientes têm acima de 60 anos, ou mesmo que teve um aumento de $40 \%$ no número de seguidores do Instagram. Pensamentos e ideias não mensuram um negócio, e não são facilmente rastreáveis. 
k. Atingível: Todo plano precisa ter um "pé na terra", ou seja, ser possível de ser atingido. Algo que seja muito distante da realidade atual do negócio, ou do profissional, facilitam para o processo de frustração do Consultor e do fracasso do Plano de Marketing. O plano precisa seguir uma direção possível, com resultados possíveis. Um Consultor que acabou de finalizar um curso de formação, dificilmente conseguirá aplicar um plano de Marketing que tem como objetivo ser o melhor do mundo em 6 meses. Acredito que nada é impossível, porém, o trabalho deve ser multiplicado, a assertividade deve ser milimétrica e a velocidade acelerada, além de pensar em possíveis contrações e maior investimento de tempo e dinheiro. Outro ponto interessante, é que quando são colocadas metas atingíveis, e caso consiga atingí-las, o Consultor sente-se energizado, autoconfiante e motivado para continuar a colocar mais metas atingíveis, e com isso os resultados vão aparecendo aos poucos e crescendo.

1. Relevante: Um Plano deve ser relevante tanto para o Consultor, quanto para a sociedade. A clareza dos motivos pelos quais ele ficará satisfeito devem estar óbvios. Ao alcançar os resultados, o que trará de bom para a vida e carreira do Consultor? Muitos acham que o dinheiro é a resposta, porém muitas vezes, só querem ter o reconhecimento dos pais, por exemplo. Quando se entende que o reconhecimento é parte importante do plano, elogios de clientes vão ser suficientes para que o plano seja cada dia mais executado com amor e carinho. Planos que estão pautados apenas em dinheiro, tendem a fracassar, pois caso demore para o dinheiro aparecer, o Consultor irá desistir e mudar novamente de profissão, ou voltar para o mercado de trabalho.

m. Tempo: Todo projeto tem uma data para terminar, assim como deve ter o Plano de Marketing. Quando se define data, as ações ficam organizadas e mais fáceis de serem executadas. Um calendário ajuda a visualizar os principais projetos mensais, depois disso é só ir detalhando as atividades por semana e por dia. Comece pelo mais amplo e vai afunilando, assim como sugeri na figura 8. Planejamento Anual de Receitas. Use esse quadro para ajudar a planejar os projetos.

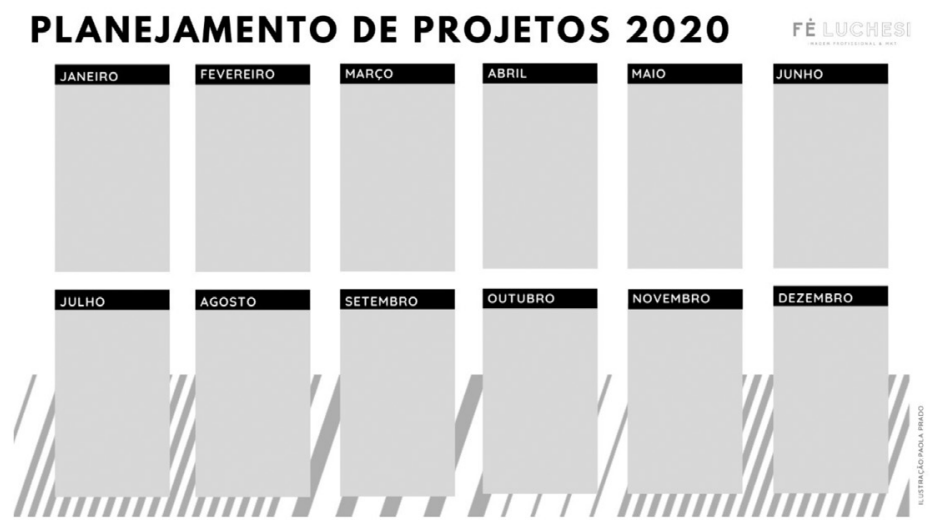

Figura 10. Planejamento Anual de Projetos. 
O trabalho é constante para criar uma mentalidade de empreendedor, onde o risco é eminente, frustrações vão acontecer, desafios vão surgir e pode demorar mais do que previsto para atingir objetivos. Se o Consultor largou tudo para investir nessa carreira, ele tem coragem, e isso já é um atributo de um empreendedor de Sucesso.

\section{Falta de Organização}

A falta de organização é o segundo pilar que irá dificultar a aplicação de um plano de Marketing eficaz.

Sabe-se que quando um negócio cresce de maneira desorganizada e desordenada ele tem grandes chances de quebrar.

A desorganização, como característica de personalidade, dificulta a clareza mental e a definição de um passo a passo. Se o Consultor identificar essa dificuldade, aconselha-se pedir ajuda e se concentrar em roteiros, mapas e processos para não se perder durante o trajeto, e perder mais tempo. A maior frustração para um desorganizado é não conseguir visualizar o processo de forma clara e ter a sensação que trabalhou muito, está esgotado, porém sem resultado.

A falta de organização dentro do negócio de Consultoria de Imagem, coopera para que um plano de Marketing também seja desorganizado ou, nem seja planejado e realizado. Ela também prejudica a sensação de vitória.

Quando perguntei para os Consultores do Brasil, "o que você deveria começar a fazer para ser mais organizado", recebi essas respostas dos 55 entrevistados pela pesquisa (Luchesi, 2020).

i. Foco e clareza de objetivos: são os assuntos que abordei no pilar um sobre falta de clareza ii. Planejar e organizar o tempo das tarefas no curto, médio e longo prazo: são os assuntos que abordo nesse pilar dois, sobre falta de organização.

iii. Disciplina e comprometimento em aplicar o plano: são os assuntos que abordarei também no pilar dois.

A falta dos pilares um e dois paralisam o consultor, e o deixa suscetível a ser levado pela rotina do dia a dia, sem perceber que suas ações podem o estar impulsionado a andar em círculos, mesmo tendo se dedicado muito. Parece básico demais, porém é extremamente importante que Consultor pare tudo que está fazendo, e permita-se responder esses pilares antes continuar a investir mais tempo e dinheiro no negócio. Esse processo pode durar um dia ou uma semana. Faça igual a empresas que saem do escritório para fazer uma viagem, ou vão para um hotel com os líderes para planejarem e fazerem o forecast do ano seguinte, e revisar os próximos anos. Procure um local agradável, calmo para pensar e escrever. Além dos ganhos de velocidade e direção, haverá o de alívio emocional. Dê o primeiro passo. Marque a data na sua agenda e faça a lista do que você tem que decidir.

Com essa clareza em mãos irá iniciar o processo de organização do tempo para colocar o planejado em ação. 


\section{a. Organização do Tempo}

Umas das maiores dores das pessoas é não conseguir realizar as ações necessárias estipuladas por elas.

Dos Consultores entrevistados $73 \%$ segue uma agenda de atividades. Sendo que $40 \%$ atingem de 80 a 100\% das atividades, e $43 \%$ seguem entre 50 e $70 \%$ da agenda. Dos que não seguem uma agenda, metade deles cumprem com $50 \%$ das atividades que estipularam, ou não conseguem cumprir nenhum.

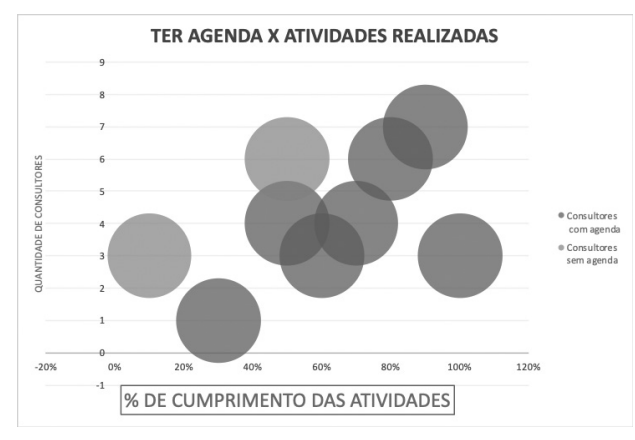

Figura 11. Gráfico Ter agenda X Atividades realizadas.

Dessa forma vimos que ter agenda é o primeiro passo para ter as atividades organizadas e realizadas. Aqueles que não tem agenda, tem rendimento muito mais inferior para realizar as atividades .

Cada profissional tem uma maneira de se organizar. Dificilmente haverá uma única solução que atenderá a todos, porém para mim funciona bem a seguinte maneira:

i. Definir o bloco de tempo que será dedicada ao profissional e pessoal, inclua todos os seus papéis, como mãe, esposa, profissional, esportista ou amiga, por exemplo.

Não existe um equilíbrio perfeito entre papéis. Você não tem como dedicar tempos iguais a todos eles...em geral, o papel profissional é sempre o que apresenta maior a dedicação do tempo. Afinal dedicamos em média $25 \%$ das horas totais de nossa semana ao trabalho (Barbosa, 2018, A Tríade do Tempo, p. 129).

ii. Incluir esses blocos vazios na agenda da semana e fim de semana.

iii. Fazer uma lista de todas as atividades pessoais e profissionais. Basei-se na figura $6 \mathrm{e}$ 10 para definir as ações relacionadas aos projetos estabelecidos daquele mês ou trimestre que precisam ser realizadas, para que o plano de Marketing seja cumprido no final do ano. 
iv. Alocar essas atividades dentro dos blocos nas suas semanas. Máximo de 5 atividades por dia. De acordo com Christian Barbosa se você quer trabalhar oito horas por dia, planeje no máximo seis horas. As duas horas são para emergências e atrasos, e planeje no máximo $70 \%$ do seu dia.

É aconselhável usar uma agenda de papel ou virtual, onde seja possível visualizar a semana toda, ou o mês todo.

v. Após a finalização de tudo, o tempo livre é bônus (30\%). Permita-se ter esse tempo para fazer algo especial, que fuja da rotina. A ancoragem da realização de funções com a recompensa, favorece a sensação de que é prazeroso ser organizado e cumprir com as atividades selecionadas.

vi. Para ancorar outra sensação positiva o Consultor pode riscar ou grifar de verde as atividades que foram realizadas. A cor verde equivale à passagem livre de que tudo está certo, e riscar os itens feitos registra um alívio de "missão cumprida!"

Desenhar esse mapa será um alívio mental. De acordo com James Clear, autor de Hábitos Atômicos (2018), os efeitos dos pequenos hábitos se multiplicam como juros compostos com o tempo. Se você conseguir melhorar um por cento cada dia, você terminará com resultados que são trinta e sete vezes melhores no ano.

São possibilidades que também necessitam de treino, e mais do que isso, uma permissão pessoal para parar um dia, ou algumas horas no começo de ano, mês, trimestre ou semestre, para colocar seus pensamentos em ordem e iniciar o processo. Mude uma pequena coisa de cada vez, que começará a mover energia para realizá-las.

\section{b. Organização da Casa e do ambiente de trabalho}

Um ambiente limpo, organizado e arrumado, tende a cooperar para o desenvolvimento de um raciocínio logico e efetivo, pois não são pontos de distração e perda de tempo. Costume organizar seu ambiente de trabalho uma vez por semana, ou mês, ou pelo menos no ano. Retire os excessos e mantenha a mesa com mais espaço possível. De acordo com o site INC.com (2017),

Estudos após estudos mostram o lado ruim de um ambiente bagunçado e confuso. Isso restringe a capacidade do cérebro de focar e processar informações. Uma mesa bagunçada é uma fonte de distração. Isso pode inclusive produzir sentimentos de culpa, vergonha, ansiedade e extrema raiva.

Ao entrarmos em um local, os nossos olhos captam a energia que ali está, se o local está revolto, nossa mente ficará revolta, confusa, consequentemente nossos sentidos ficarão inertes, sem forças para a tomada de ações; nessa linha de raciocínio, quando começamos a arrumar nossas coisas, arrumamos nossa mente e levamos nossos sentimentos a uma gradual organização interna, mais rápida ou mais demorada, não importa, mesmo porque o tempo é relativo a cada personalidade, o que interessa aqui é que isso nos traz constância, calma 
e força para aplacar as bagunças internas e tomarmos atitudes a partir das ordenações que fazemos (Pereira, 2015).

Uma das vantagens para os Consultores de imagem é não ter a necessidade de ter um escritório fora de casa para trabalhar. No entanto é primordial que se estabeleça um espaço profissional para a realização do trabalho. Onde dificulte ocasionais distrações e que seja apropriado para as atividades de escritório. Que tenha os equipamentos adequados de impressão, cadeira, mesa, computador, luz e conforto. Sentir prazer em seu ambiente de trabalho é gratificante e favorece uma melhor concentração nas atividades diárias do plano. Quanto menos distrações aleatórias, melhor para a produtividade do Consultor. Deve-se observar se o ambiente é apropriado para a imagem do Consultor, caso tenha que se fazer um vídeo ou receber alguém.

\section{c. Disciplina}

Uma das grandes verdades é que muitas pessoas têm iniciativa, e poucas tem "acabativa", como diz no livro Projeto Cliente (2009). O fator determinante para que isso aconteça é a disciplina de manter suas ações em uma velocidade constante, pode ser até devagar, mas que seja sempre. O sucesso de um plano de Marketing, ou de aprender uma língua nova, é treinar sempre, apensar de todas as dificuldades "ou você vai ter desculpas, ou vai ter resultados". Entender que seu sucesso, é um conjunto de ações diárias, de falhas e acertos, às vezes muito mais de erros, do que de acertos, lhe dará mais clareza que a jornada é tão importante quanto o destino. Ninguém que nunca correu, irá terminar uma maratona na primeira levantada da cadeira. Ela terá que treinar, se disciplinar a correr um pouco a mais todo dia, para conseguir atingir os quilômetros necessário de uma maratona. Sem o treino regular .ela não se completa. Todos podem, porém somente os que têm disciplina conseguem o resultado.

"Eu preciso de mais disciplina. Na verdade, você precisa do hábito da disciplina. E precisa de disciplina suficiente para criar o hábito. Elas intersectam. Os dois juntos significam conquistas" (Keller \& Papasan, 2013, The one thing).

É exatamente assim com um plano de Marketing. Se nesse plano está escrito que alimentar as redes sociais é importante, não adiantará alimentar uma vez ao mês, ou a cada três meses e ter a expectativa que seu posicionamento, autoridade e relevância vão aumentar. O trabalho deve ser constante e sempre, pode não ser rápido, mas não deve parar. Todo negócio tem um período de maturação e a mesma coisa acontece com o negócio de consultoria de Imagem. Dessa forma, ter paciência, persistência e disciplina são primordiais para um plano de Marketing aplicado com sucesso.

“Um 'Sim' deve ser defendido ao longo do tempo por 1.000 'Nãos”' (Keller, 2013). 


\section{d. Treino}

Para conseguir finalizar bem uma maratona, é necessário treinar. A disciplina lhe fará não faltar ao treino, porém se o treino for fraco, ou não mostrar um processo evolutivo, $o$ resultado na Maratona será aquém do esperado. Dificilmente haverá valor monetário no negócio se apenas houver disciplina para estudar as melhores técnicas, sem aplicá-las no dia a dia. Precisa ter a oportunidade de poder medir os resultados, e assim conseguir evoluir a cada momento. Esse treino contínuo irá contribuir para que o Consultor tenha cada dia mais autoconfiança em seu trabalho e aprenda a melhorar em cada ação praticada. Ele terá a oportunidade de exercitar o seu talento.

"Sem esforço, a pessoa talentosa não vai longe. Já com os dois quesitos...ah, ela se torna imbatível. Terá mais sucesso do que outra apenas esforçada" (Moraes, 100\% presente, p. 159).

\section{e. Organização da Saúde}

A energia necessária para enfrentar uma jornada de trabalho, muitas vezes solitária, é muito alta. Principalmente quando todas as responsabilidades caem em cima de uma pessoa apenas. Trabalhar a conexão entre corpo, mente e espírito podem contribuir para uma rotina mais equilibrada e energizar a saúde.

Esses três elementos devem estar contemplados na agenda de atividades do Consultor.

De acordo com a pesquisa de fevereiro de 2020 (Luchesi, 2020), os 55\% dos Consultores cuidam do corpo de duas a três vezes na semana, $38 \%$ cuida da mente duas a três vezes na semana, $27 \%$ cuida do espiritual de duas a três vezes. Ou seja, os Consultores tendem a cuidar em primeiro lugar do corpo, depois mente e por último do espiritual. Não necessariamente os três precisam estar classificados em partes iguais. O importante é dedicar algumas atividades para eles dentro da agenda. Quando eles estão em harmonia, a saúde e energia vital florescem para dar mais vitalidade no Consultor.

Dessa forma, quando esses cinco itens relacionados à organização são desenvolvidos (Tempo, Casa/trabalho, disciplina, treino, saúde), podem cooperar imensamente para o sucesso do Plano de Marketing.

\section{Falta de habilidades}

Por último, o terceiro pilar da Tríade do Plano de Marketing Feliz é a falta de habilidades. Se o Consultor não estiver conseguindo atingir os objetivos dele, claramente tem algo que ele não sabe ainda. Friamente dizendo, ele não consegue aplicar o plano de Marketing porque não sabe, que não sabe. Ele deixa a rotina e os problemas do dia a dia, que vão aparecendo sem parar, façam com que ele não perceba, que sem certas habilidades não conseguirá ter o resultado que ele espera. Os Consultores de Imagem são profissionais autônomos, ou seja, iniciam o trabalho sozinhos, porém com informações e dados do mercado de grandes empresas. Como vimos a profissão não exige muito capital para ser 
investido em aluguel, colaboradores, estoque, taxas, permissões, certificações e faculdades. Dessa forma é uma profissão de baixo custo e baixa barreira de entrada, porém, para que o negócio cresça é necessário investimento e habilidades. O que se analisa no mercado, é uma expectativa de ganhar dinheiro antes e investir depois, o que dificilmente acontece, como já citado acima. O pouco investimento inicial e a pouca paciência contribuem para uma gestão de negócio amadora e com resultados ínfimos.

"É possível observar que a taxa de sobrevivência tem uma relação direta com o porte da empresa: empresas com mais pessoas assalariadas tendem a permanecer mais tempo no mercado. Já nas faixas de menor número de pessoas ocupadas assalariadas, as taxas de sobrevivência são menores", IBGE (2015), no relatório da pesquisa Demográfica das Empresas.

De acordo com algumas linhas de treinamento em negócios do T. Harv Eker, Guerrila Business Intensive (2008), o foco do negócio deve ser em Marketing e Vendas. No entanto poucos são os Consultores que têm uma formação acadêmica nessas áreas, ou contrata alguém para fazer essas funções. A falta de habilidade nessas áreas coopera para que seja nula, ou inexistente uma atuação consistente, focada e direcionada para criar aweraness no mercado e aumento de faturamento e lucratividade.

\section{a. Marketing}

O trabalho de autoconhecimento de um negócio é realizado normalmente por agências de Marketing e publicidade quando contratadas por empresas grandes. Porém esse não é o caso dos Consultores de Imagem que são seus CEOs, COO, CFO, CMO, entre outros "C", porém sem receber o salário como tal. Um Consultor necessita estar ciente das consequências ao não conseguir implantar uma estratégia de Marketing para seu negócio.

De acordo com a American Association of Marketing (AMA), a definição de Marketing seria: "Marketing é a atividade, conjunto de instituições e processos para criar, comunicar, entregar e trocar ofertas que têm valor para consumidores, clientes, parceiros e sociedade em geral" (Jaworski, Lutz, Marshall, Price \& Varadarajan, 2017).

Hoje o Marketing está totalmente renovado. Além de entender de estratégias para criar valor para seus clientes, deve-se entender de tecnologia, pois tudo é online e usa-se softwares e canais digitais para aplicação do Plano de Marketing. Hoje se fala muito mais em Marketing Digital, que de acordo com a American Association of Marketing (AMA), seria:

Marketing digital é o uso de canais digitais ou sociais para promover uma marca ou alcançar consumidores. Esse tipo de Marketing pode ser executado nas mídias sociais, mecanismo de busca, internet, dispositivos móveis e outros canais. Requer novas formas de Marketing para os consumidores e a compreensão do impacto de seu comportamento (AMA).

De acordo com a pesquisa do Negócio de Consultoria de Imagem (Luchesi, 2020), 33\% dos Consultores de Imagem se deram nota oito a dez em relação ao seu conhecimento de Marketing Digital. No entanto $58 \%$ acredita que ele influência $100 \%$ nas vendas, $22 \%$ que 
influencia $90 \%$ e $11 \%$ que ele influencia $80 \%$, ou seja $90 \%$ acredita que ele influencia nas vendas de 80 a 100\%. Podemos afirmar que se as vendas estão baixas, pode ser atrelado ao Marketing ineficiente.

Essas habilidades natas ou adquiridas em Marketing são essenciais para ter facilidade em aplicar o plano com coerência e dinamismo. Os experts em Marketing são pessoas que planejam, aplicam, testam e medem resultados o tempo inteiro. Um Consultor que se arrisca em fazer a mesma coisa, tende a crescer e ter resultados mais rápidos, pois está rapidamente averiguando os possíveis erros de sua rota e ajustando os detalhes para a melhora constante. O medo de errar junto com a falta de conhecimento paralisam o Consultor e abre oportunidades para seu competidor abocanhar o seu espaço. Concordo com a teoria da professora de Harvard Youngme Moon, que afirma que devemos investir o nosso tempo em desenvolver os seus pontos fortes para que o diferencial do Profissional seja claramente muito superior ao seu meio. No entanto o Marketing e Vendas serão os responsáveis em pulverizar e materializar os pontos fortes, impulsionando o negócio. Dessa forma, uma noção básica desses temas pode ajudar ao Consultor a se destacar no seu mercado, pois não são muitos os Consultores com uma noção básica. Além do mais, facilitará para orientar algum profissional da área que queira contratar. Ao passar do conhecimento básico, o potencial competitivo também aumentará significamente.

\section{b. Vendas}

Toda vez que se pede para levantar a mão, as pessoas que gostam de vendas são a minoria. Quando perguntei na pesquisa (Luchesi, 2020) se os Consultores de Imagem gostam de Vendas, $62 \%$ deram uma nota de sete para baixo, apenas 38\% deu uma nota de oito a dez. Existe uma barreira e preconceito de ser uma pessoa "vendedora". Costumo dizer para meus alunos que "ou você aprende a vender, ou contrata alguém para fazer para você." A falta de inabilidade com a venda resulta num ciclo muito maior de tempo para que uma venda aconteça de fato. A ansiedade e incerteza podem aumentar, atrapalhando o emocional e a confiança de um Consultor. Se o objetivo é viver das Consultorias, vendas precisam ser realizadas. Caso, todas as etapas anteriores desse artigo forem cumpridas, haverá uma boa parte de leads qualificados prontos para receber uma oferta irresistível e comprar. No entanto, se o "eu vendedor", tiver vergonha de vender, todo trabalho de Marketing irá por água abaixo. Compradores estão querendo comprar, porém precisam de um estímulo, um lembrete para que seja realizada a ação. A mensagem de venda deve ser clara e haver um "call to action", ou seja, uma chamada para a ação. A audiência precisa entender que algo está sendo oferecido e está disponível para a venda. Os gatilhos mentais são aliados na comunicação persuasiva e agilizará a tomada de decisão do potencial cliente. Existem muitos gatilhos, porém os mais conhecidos e efetivos para a venda são: escassez, autoridade e prova social.

Gatilhos mentais são estímulos recebidos pelo nosso cérebro que influenciam diretamente a nossa tomada de decisão. Saber estimular esses gatilhos é uma poderosa arma de persuasão e geração de resultados para Marketing e Ven- 
das. Todos os dias nós tomamos até 35.000 decisões, que vão desde escolher a roupa que vamos vestir, a comida que vamos comer, atitudes cotidianas como caminhar ou até de ler esse post! Inclusive, todas as coisas que escolhemos não fazer também são decisões. Todas elas são baseadas em uma série de aspectos, internos e externos, relacionados a humor, expectativa, bagagem, cultura e etc, que despertam em nós uma espécie de click entre fazer A ou B. E é claro que essas decisões também estão diretamente relacionadas ao consumo. Por isso, entender os critérios que levam as pessoas a optar por uma coisa no lugar de outra pode fazer toda a diferença na hora de elaborar a sua estratégia de Marketing... É a partir desse comportamento ativado pelos gatilhos mentais que muitas marcas elaboram campanhas ou promoções para que, de alguma maneira, uma pessoa se sinta incentivada a realizar uma compra que, sem essas motivações, talvez não faria ou adiaria (website Rock Content, 2019).

\section{i. Escassez}

As pessoas não gostam da sensação que estão perdendo algo. A escassez acessa um sentimento de que se não for tomado uma atitude, algo será perdido e a oportunidade irá passar. Tende-se a querer aquilo que é exclusivo. Ao incluir um gatilho de escassez de tempo (faltam 2 dias), vagas (somente 15 vagas), lote (lote 1 esgotado), preço (aumentará o preço no dia $\mathrm{x}$ ), ou bônus ( apenas para os 5 primeiros), fará com que os potenciais clientes tomem uma decisão mais rápida do que normalmente tomariam.

\section{ii. Autoridade}

Títulos acadêmicos, fama e veículos de comunicação passam uma sensação de autoridade, pois foram "aprovados" pela sociedade. A autoridade faz com que as pessoas tendam a confiar e se abrirem para ouvir mais. Ao atrelar o nome ou empresa do Consultor de Imagem com algo que já tem credibilidade, irá transferir essa autoridade para o Consultor. Uma certificação internacional de uma associação de classe global, como a da AICI, tende a passar mais credibilidade do que uma Certificação dada por uma pessoa física sem autoridade global.

O uso desse gatilho faz com que o cliente coloque o Consultor na "caixinha mental" na sessão de profissional especial qualificado. Esse gatilho é um grande aliado de desempate entre profissionais.

\section{iii. Prova Social}

Para escolher um produto ou serviço, o potencial cliente precisa confiar. O fator confiança está muito mais ativado nos dias atuais já que existem muitas pessoas fazendo a mesma coisa. Quando outras pessoas já fizeram essas escolhas "difíceis" e gostaram, o potencial cliente tende a sentir-se aliviado e mais seguro, pois alguém já aprovou o serviço para ele. Dessa forma, é muito importante e estratégico sempre apresentar depoimentos e provas de que seus clientes aprovaram o serviço a ser oferecido. 
As outras ações das campanhas de Marketing servem para aumentar o interesse do potencial cliente, e a comunicação de vendas serve para finalizar o ciclo (vide na figura abaixo). Lembrando que o conteúdo precisa ser de qualidade e agregar na vida do público alvo.

\section{O CICLO - MKT \& VENDAS}

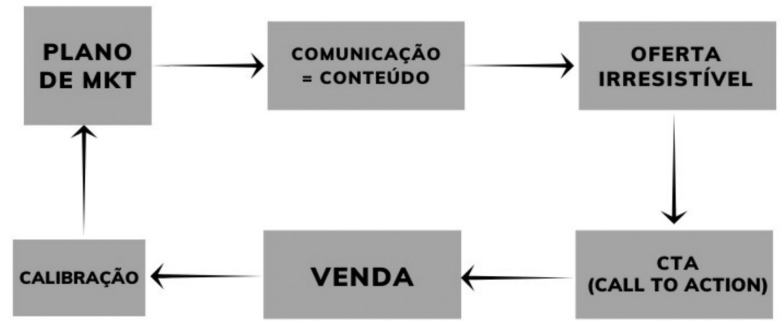

Figura 12. Ciclo Mkt e Vendas. Ilustração Paola Prado.

\section{A prática}

Todo processo de mudança inicia com a identificação do problema, para depois identificar onde está o ponto de melhoria, e em seguida criar ações para mudar o status atual. Ao analisar a figura abaixo da tríade do Plano de Marketing Feliz, faça uma análise do Negócio e defina uma nota de zero a dez em cada um dos itens. Ao final some todos os valores. Destaque quais são os itens que estão abaixo de seis.

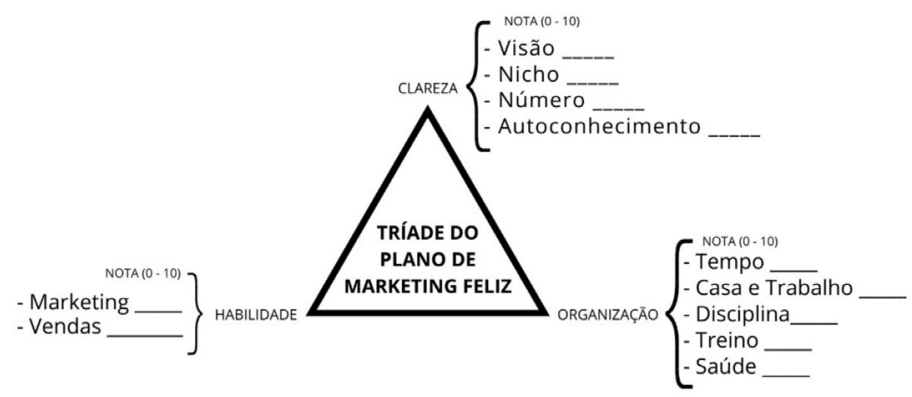

Final: 110/

Figura 13. Tríade do Plano de Marketing Feliz. 
Esses itens abaixo de seis, são os pontos de atenção mais graves. Defina as ações necessárias para aumentar a média deles. Saliento que não necessariamente todos necessitam estar com nota máxima. Ao estarem acima de seis já haverá um desempenho acima da média em relação aos concorrentes.

O empreendedorismo exige resiliência, paciência e atitude. Se sozinho o Consultor não está atingindo seus objetivos, peça ajuda para os especialistas que cuidem das áreas abaixo da média.

\section{Conclusão}

O Marketing Digital pode ser o caminho do sucesso, se assim o Consultor o encarar como um caminho importante. Como todas as áreas, quem consegue aplicar as teorias que aprende se destaca e ganha mais mercado.

Use a pirâmide abaixo para se lembrar de todas as etapas para conseguir realizar e aplicar um plano de Marketing. Aumente a média nos três pilares e sinta-se orgulho do seu negócio. Ao realmente montar, aplicar e reavaliar o Plano de Marketing o Consultor construirá para trilhar o caminho do seu sucesso mais rapidamente e poderá mudar a vida de muito mais pessoas.

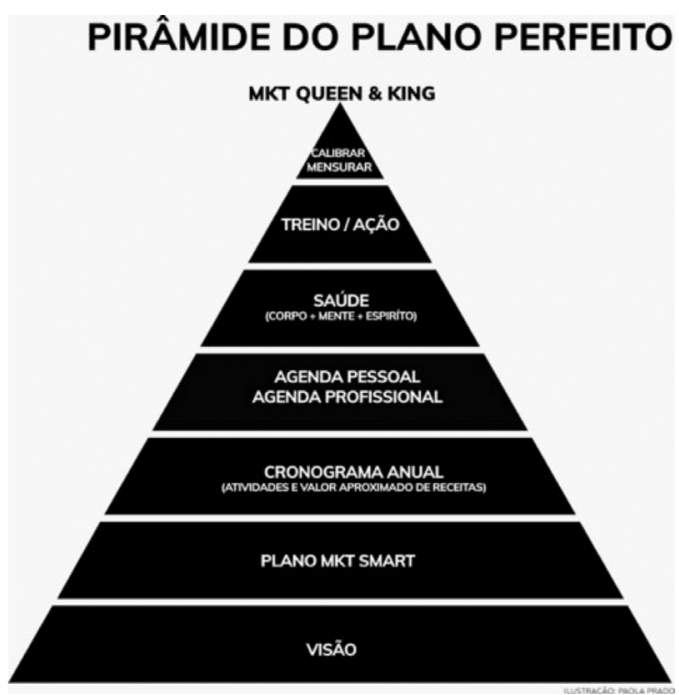

Figura 14. Pirâmide do Plano Perfeito. 
Ajude o Marketing a lhe ajudar. Ele pode ser o seu melhor amigo e mentor.

Ele nada mais é do que um grande veículo que levará aos ouvidos do público a história do negócio. Quanto mais sincera e clara essa história for, mais pessoas vão querer ouvir.

\section{Referências Bibliográficas}

Adolpho, C. (2018). Treinamento Método 8Ps. São Paulo.

Alves, F. (2016). Melhores Hábitos, Por que você deveria comemorar até as pequenas conquistas. Disponível em: http://melhoreshabitos.com.br/porque-voce- deveria-comemorarconquistas/ Acesso em fevereiro 2020.

Amabile, T. (2011). TEDx Atlanta, Disponível em: https://www.youtube.com/watch?v= XD6N8bsjOEE Acesso em fevereiro 2020.

Andrade, R. et al. (2016). Sebrae. Sobrevivência das Empresas no Brasil. Disponível em: https:// www.sebrae.com.br/Sebrae/Portal\%20Sebrae/Anexos/sobrevivencia-das-empresas-nobrasil-relatorio-2016.pdf Acesso em janeiro 2020.

Barbosa, C. (2018). A tríade do tempo - Família, trabalho e vida. Editora Buzz. (p. 129 e 199).

Bendec, A. (2009). Personal Branding- Construindo sua marca Pessoal. Editora Integrare. (p. 141).

Bôas, B. (2017). Site Valor Econômico. Maioria das empresas fecha as portas após cinco anos, diz IBGE, Disponível em: https://valor.globo.com/brasil/noticia/2017/10/04/maioria-dasempresas-fecha-as- portas-apos-cinco-anos-diz-ibge.ghtml . Acesso em fevereiro 2020.

Bolina, L. (2018, atualizado em 2019). Rock content. O que são gatilhos mentais e como utilizá-los na sua estratégia de Marketing! Disponível em: https://rockcontent.com/blog/ gatilhos-mentais/ . Acesso em fevereiro 2020

Clear, J. (2018). Atomic Habits - Tiny changes remarkable results. An Easy \& Proven way to build good habits \& break bad ones. Intérprete James Clear. Audiolivro.

Covey, S. R. (2003). The 7 habits of highly effective people. Powerful lessons in personal Change. Intérprete Stephen R Covey. Audiolivro.

Dweck, C.S., ph.D, (2017). Mindset. A nova psicologia do sucesso. Editora Objetiva. Intérprete Marguerite Gavin. Audiolivro.

Eker, T. H. (2008). Guerrila Business Intensive Training. São Paulo.

Jaworsk, B.; Lutz, R.; Marshall, G. W.; Price, L. \& Varadarajan, R. (2017). Definitions of Marketing. Disponível em: https://www.ama.org/the-definition-of-marketing-what-ismarketing/ . Acesso em fevereiro 2020.

Keller, G. \& Papasan, J. (2013). The one thing. The surprisingly simple truth behind extraordinary results. Intérprete Timothy Miller, Claire Hamilton. Audiolivro.

Luchesi, F. (2020). Pesquisa Informações do Negócio da Consultoria de Imagem no Brasil. Disponível em: http://0f42456.contato.site/pesquisaartigo . Acesso em fevereiro 2020.

Manson, M. (2016). The subtle art of not giving a $F^{*} c k$. Intérprete Roger Wayne. Audiolivro.

Marcos, E. e Moreira, M. (2014). Sebrae-SP. Causa mortis.O sucesso e o fracasso das empresas nos primeiros 5 anos de vida. Disponível em: https://www.sebrae.com.br/Sebrae/Portal\%20 Sebrae/UFs/SP/Anexos/causa_mortis_2014.pdf . Acesso em janeiro 2020. 
Marins, L. (2009). Projeto cliente - Uma metodologia simples para aumentar vendas, surpreender e encantar clientes. Editora Harbra

Moon, Youngme. "Youngme Moon - Faculty - Harvard Business School". www.hbs.edu.

Moraes, J. (2019). 100\% presente - O poder da disciplina, do foco e dos minihabitos para conseguir realizar seu potencial máximo. Editora Gente (p. 159).

Pereira, G. (2015). Site mundo dos Psicólogos. Espaços desorganizados, mentes desorganizadas. Disponível em: https://br.mundopsicologos.com/artigos/espacos- desorganizadosmentes-desorganizadas . Acesso em fevereiro 2020.

Ramos, et al. (2015). IBGE, Demografia das Empresas. Disponível em: https://biblioteca. ibge.gov.br/visualizacao/livros/liv101151.pdf . Acesso em fevereiro 2020.

Ries, A. e Trout, J. (2006) . Positioning - The battle for your mind. How to be seen and heard in the overcrowded marketplace. Intérprete Grover Gardner. Audiolivro.

Rocha, E. (2016). Sacadas de empreendedor. Editora Buzz.

Shaefer, M. W. (2017). Know - the handbook for building and unleashing your personal brand in the digital era. Intérprete Mark W. Schaefer. Audiolivro.

Tabaka, M. (2017). Leave That Messy Desk Alone. Studies Say There's a Benefit to Clutter, INC, Disponível em: https://www.inc.com/marla-tabaka/leave-that-messy- desk-alonestudies-say-theres-a-benefit-to-clutter.html . Acesso em fevereiro 2020.

Trafton, A. (2011). MIT News Office. How the brain assigns objects to categories. Disponível em: http://news.mit.edu/2011/category-learning-0727 Acesso em janeiro 2020.

Resumen: El propósito de este artículo es informar a Image Consultants cuáles son los elementos principales que afectan el desempeño positivo, efectivo y ágil del plan de Marketing en sus negocios. Además de indicar algunas formas de resolver estos desafíos. Hubo años de estudios en el área de Marketing y Comunicación, además de aplicaciones prácticas en el mundo de Image Consulting. Obtuve información y conocimiento a través de los resultados en mi negocio, de mis alumnos y aprendices, además de la investigación. Concentré los errores más comunes en tres pilares que llamaré la Tríada del Plan de Marketing. Son la falta de claridad, la falta de organización y la falta de habilidades. El mercado necesita Image Consultants, y su misión es hacer que te encuentren y quieran tus servicios, a través del Marketing.

Palabras clave: Plano de Marketing - Marketing Digital - Asesor de Imagen - Asesoria de Imagen - Marketing y Ventas.

Abstract: The purpose of this article is to inform Image Consultants what are the main elements that affect the positive, effective and agile performance of the Marketing plan in their business. In this article are indicated some paths to these challenges. There were years of studies in the area of Marketing and Communication, in addition to practical applications in the world of Image Consulting. Acquire information and knowledge through the results in business, from students and mentors, in addition to research. Focus on the most 
common mistakes in three pillars that will be called the Marketing Plan Triad. They are, lack of clarity, lack of organization and lack of skills. The market is in need of Image Consultants, and your mission to help people find and want your service, through Marketing.

Keywords: Marketing Plan - Digital Marketing - Image Consulting - Image Consultant Marketing - Marketing and Sales.

[Las traducciones de los abstracts fueron supervisadas por el autor de cada artículo] 